\title{
The relationship between nasal septal body size and allergic rhinitis and sinonasal pathologies
}

\section{Nazal septal cisim boyutu ile sinonazal patolojiler ve alerjik rinit arasindaki ilişki}

\author{
Kübra Çoban (1), M. Volkan Akdoğan (D), Işıllay Öz (D) \\ Department of Otolaryngology, Başkent University Faculty of Medicine, Ankara, Turkey
}

\section{ABSTRACT}

Objectives: This study aimed to investigate and compare the width of nasal septal body (NSB) in patients with and without allergic rhinitis (AR) and other sinonasal pathologies.

Patients and Methods: A total of 577 individuals were included in the study. The study groups consisted of 488 adult patients with various sinonasal pathologies and/or AR; while the control group consisted of 89 healthy individuals whose paranasal radiographic findings and allergy tests were completely normal. Four groups were formed in total: group 1 consisted of patients who only had sinonasal pathologies (septum deviation, acute sinusitis, chronic sinusitis with/without nasal polyposis), group 2 consisted of patients with both sinonasal pathologies and AR, group 3 consisted of patients who were only diagnosed with AR, and group 4 was designed as the control group.

Results: There were 201 (34.8\%) patients in group 1, 211 (36.6\%) patients in group 2, $76(13.2 \%)$ patients in group 3, and, $89(15.4 \%)$ healthy individuals in group 4 . Of these, 299 (51.8\%) were female, $278(48.2 \%)$ were male. NSB was significantly larger in males than females. The mean NSB width was $1.2 \pm 0.2 \mathrm{~cm}$. NSB body was significantly larger in all three study groups when compared to the control group $(\mathrm{p}<0.001)$.

Conclusion: Our study is consistent with the literature, which supports that NSB enlarges in AR and sinus pathologies. In patients presenting with nasal obstruction, evaluation with paranasal sinus tomography in addition to physical examination is of great importance for effective diagnosis and treatment.

Keywords: Allergic rhinitis, nasal septal body, sinusitis.
$\ddot{O} Z$

Amaç: $\mathrm{Bu}$ çalışmada alerjik rinit (AR) ve diğer sinonazal patolojileri olan ve olmayan hastalarda nazal septal cisim genişliğinin (NSC) araştırılması ve karşılaştırılması amaçlandı.

Hastalar ve Yöntemler: Çalışmaya toplam 577 birey dahil edildi. Çalışma grupları, çeşitli sinonazal patolojileri ve/veya AR'si olan 488 erişkin hastadan, kontrol grubu ise paranazal radyografik bulguları ve alerji testleri tamamen normal olan 89 sağlıklı bireyden oluşuyordu. Çalışma grubundaki hastalar kendi içinde dört gruba ayrrlarak incelendi; grup 1 sadece sinonazal patolojisi olan hastalar (septum deviyasyonu, akut sinüzit, kronik sinüzit ve/veya nazal polipozis), grup 2 hem sinonazal patolojileri hem de AR'si olan hastalar, grup 3 sadece AR tanılı hastalardan oluşturuldu, grup 4 ise kontrol grubu olarak tasarland.

Bulgular: Grup 1'de 201 (\%34.8) hasta, grup 2'de 211 (\%36.6) hasta, grup 3'de 76 (\%13.2) hasta ve grup 4'de ise 89 sağlıklı birey (\%15.4) mevcuttu. Bunlardan 299'u (\%51.8) kadın, 278'i (\%48.2) erkekti. NSC erkeklerde kadınlardan anlamlı olarak daha büyüktü. Ortalama NSC genişliği $1.2 \pm 0.2$ idi. NSC boyutları her üç çalışma grubunda da kontrollere kıyasla anlamlı olarak daha büyüktü $(\mathrm{p}<0.001)$.

Sonuç: Çalışmamız, literatür ile uyumlu olarak NSC'nin $A R$ ve sinus patolojilerinde benzer oranlarda büyüdüğünü desteklemektedir. Burun tıkanıklığı ile başvuran hastalarda, fizik muayeneye ek olarak paranazal sinüs tomografisi ile değerlendirme etkin tanı ve tedavi için büyük öneme sahiptir.

Anahtar sözcükler: Alerjik rinit, nazal septal cisim, sinüzit.

Received: June 08, 2020 Accepted: August 09, 2020 Published online: October 05, 2020

Correspondence: Kübra Çoban, MD. Başkent Üniversitesi Alanya Uygulama ve Araştırma Merkezi, Kulak Burun Boğaz Kliniği, 07400 Alanya, Antalya, Türkiye. e-mail: kubracob81@gmail.com 
The nasal septal body (NSB) is an anatomic structure that is often overlooked. It is composed of relatively thick cartilage and mucosa located in the anterior region of the septum. It is observed as a soft tissue thickness located at the superior of the inferior nasal turbinate and anterior to the middle nasal turbinate. ${ }^{[1-4]}$ Nasal septal body is often confused with high septal deviation. ${ }^{[3]}$ In this sense, paranasal sinus computed tomography (PNS-CT) examination in NSB evaluation may be necessary. This swollen area in the septum is a dynamic structure and consists of extensive vasoactive glandular tissues. ${ }^{[1,2,4]}$ Thus NSB is similar to the nasal turbinates due to its structural configuration and functions. ${ }^{[4]}$

This complex functional structure appears to be directly related to nasal airflow, but very limited information regarding NSB has been encountered in related literature. This study aims to investigate whether or not NSB changes in sinonasal pathologies and allergic rhinitis (AR).

\section{PATIENTS AND METHODS}

This retrospective study was conducted at the Başkent University Faculty of Medicine Otolaryngology Department between September 2019 and December 2019. Informed consent was obtained from all individual participants included in the study. All procedures in studies involving human participants were performed by following the ethical standards of the institutional and/or national research committee Başkent University Faculty of Medicine Institutional Review Board and Ethics Committee (Project no: KA19/302, Date: September 10, 2019) and in accordance with the 1964 Declaration of Helsinki and its later amendments or comparable ethical standards.

A total of 577 individuals were enrolled. The study groups included 488 adult patients with various sinonasal pathologies and AR confirmed with PNS-CT, serum levels of total immunoglobulin (Ig) E, and skin prick tests (SPTs); while the control group consisted of 89 patients who had PNS-CT for various complaints other than otorhinolaryngologic ones and whose SPTs were negative, and with serum levels of Ig $\mathrm{E}$ and radiographic findings within normal limits.

Four groups were formed in total. Group 1 consisted of patients with only sinonasal pathologies (septum deviation, acute sinusitis, chronic sinusitis with or without nasal polyposis), Group 2 included patients with both sinonasal pathologies and AR, Group 3 consisted of patients diagnosed with AR, and Group 4 was designed as the control group.
Study group exclusion criteria:

- $\quad \leq 18$ years of age

- Patients who received local or systemic treatment for their sinonasal and/or allergic complaints before paranasal CT scanning

- History of facial trauma and/or sinonasal surgery

- Comorbid systemic disease, infections or malignancies,

- Sinonasal malignancies,

- Generalized nasal polyposis that prevents NSB measurement

- Patients with paranasal CT images not suitable for NSB measurements

Control group exclusion criteria:

- $\quad \leq 18$ years of age

- History of facial trauma and/or sinonasal surgery,

- Diagnosis of chronic systemic diseases, infections or malignancies

- History of allergic disease, positive SPTs, and/or increased serum Ig E levels

- Individuals with paranasal CT images unsuitable for NSB measurement

Demographic data of groups were recorded and presence of septal deviation (SD), acute sinusitis (AS),

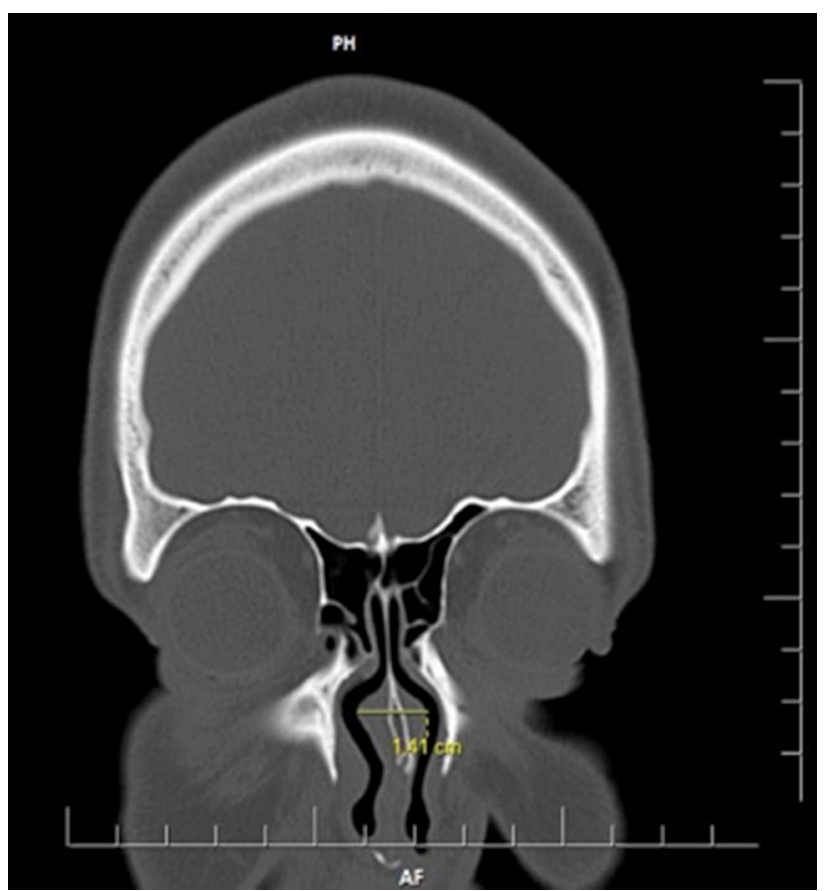

Figure 1. In paranasal computed tomography, measurement was made from the widest part of the nasal septal body horizontally. 
chronic sinusitis (CS) with and without nasal polyposis were investigated and noted. Skin prick test results and serum Ig E levels were recorded in all patients and controls.

Skin prick test was performed with standardized allergen extracts (Dermaatophagoides Pteronyssinus, Dermatophadoides Farinea, grass mix pollen, grain mix pollen, weed mix pollen, Blatella Germanica (cockroach), cat and $\operatorname{dog}$ epithelium, latex, Plantain plantago, Parieteria Officinalis, Betula Betulaceae, Artemisia Vulgaris, fungi (Cladosporium, Alternaria Alternata, Aspergillus, Penicillium mixture), Olea Europea (olive), tomato, banana, kiwi, peach, strawberry, egg white, egg yolk, chicken meat, Petroselinum crispum, Almond, Walnut, Hazelnut, Peanut (Allergopharma D-21462 Reinbek, Germany) with the technique standardized by the European Academy of Allergy and Clinical Immunology. ${ }^{[5]}$ Clinical diagnosis of AR was made according to ARIA guidelines. ${ }^{[6]}$ Acute and chronic sinusitis diagnoses were made according to The American
Academy of Otolaryngology-Head and Neck Surgery Adult Sinusitis guidelines and Lund-Mackay score. ${ }^{[7,8]}$

Paranasal CTs were evaluated by a senior otorhinolaryngologist, who was blinded to the study. The widest region of NSB mucosa in coronal sections of paranasal CT was measured (Figure 1). Two consecutive measurements were made. The average of the values was noted. Mean nasal septal body widths, and patients with NSB greater than $1.5 \mathrm{~cm}$ were compared. We investigated whether or not NSB width differed according to age and gender. Results were analyzed for statistical significance.

\section{Statistical analysis}

IBM SPSS version 25.0 software (IBM Corp., Armonk, NY, USA) was used to analyze the variables. The suitability of the data for normal distribution was evaluated by Lilliefors corrected KolmogorovSmirnov test and variance homogeneity was evaluated by Levene. Independent-samples t-test was used

\begin{tabular}{|c|c|c|c|c|c|}
\hline \multicolumn{6}{|c|}{$\begin{array}{c}\text { Table } \mathbf{1} \\
\text { Demographic distribution and sinonasal pathologies of the groups }\end{array}$} \\
\hline & $\mathrm{n}$ & $\%$ & Mean \pm SD & Median & Min-Max \\
\hline Age (year) & & & $40.7 \pm 14.6$ & 38 & $18-86$ \\
\hline Nasal septal body & & & $1.2 \pm 0.2$ & 1.17 & $0.6-1.99$ \\
\hline $\begin{array}{l}\text { Groups } \\
1 \\
2 \\
3 \\
\text { Control }\end{array}$ & $\begin{array}{c}201 \\
211 \\
76 \\
89\end{array}$ & $\begin{array}{l}34.8 \\
36.6 \\
13.2 \\
15.4\end{array}$ & & & \\
\hline $\begin{array}{l}\text { Sex } \\
\text { Female } \\
\text { Male }\end{array}$ & $\begin{array}{l}299 \\
278\end{array}$ & $\begin{array}{l}51.8 \\
48.2\end{array}$ & & & \\
\hline $\begin{array}{l}\text { Nasal septal body } \\
\quad<1.5 \\
\quad \geq 1.5\end{array}$ & $\begin{array}{c}541 \\
36\end{array}$ & $\begin{array}{l}93.8 \\
6.2\end{array}$ & & & \\
\hline $\begin{array}{l}\text { Septal deviation } \\
\text { Absent } \\
\text { Present }\end{array}$ & $\begin{array}{c}53 \\
359\end{array}$ & $\begin{array}{l}12.9 \\
87.1\end{array}$ & & & \\
\hline $\begin{array}{l}\text { Acute sinusitis } \\
\text { Absent } \\
\text { Present }\end{array}$ & $\begin{array}{c}377 \\
35\end{array}$ & $\begin{array}{c}91.5 \\
8.5\end{array}$ & & & \\
\hline $\begin{array}{l}\text { Chronic sinusitis } \\
\text { Absent } \\
\text { Unilateral } \\
\text { Bilateral }\end{array}$ & $\begin{array}{c}301 \\
103 \\
8\end{array}$ & $\begin{array}{c}73.1 \\
25.0 \\
1.9\end{array}$ & & & \\
\hline $\begin{array}{l}\text { Nasal polyposis } \\
\text { Absent } \\
\text { Unilateral } \\
\text { Bilateral }\end{array}$ & $\begin{array}{c}383 \\
28 \\
1\end{array}$ & $\begin{array}{l}93.0 \\
6.8 \\
0.2\end{array}$ & & & \\
\hline
\end{tabular}




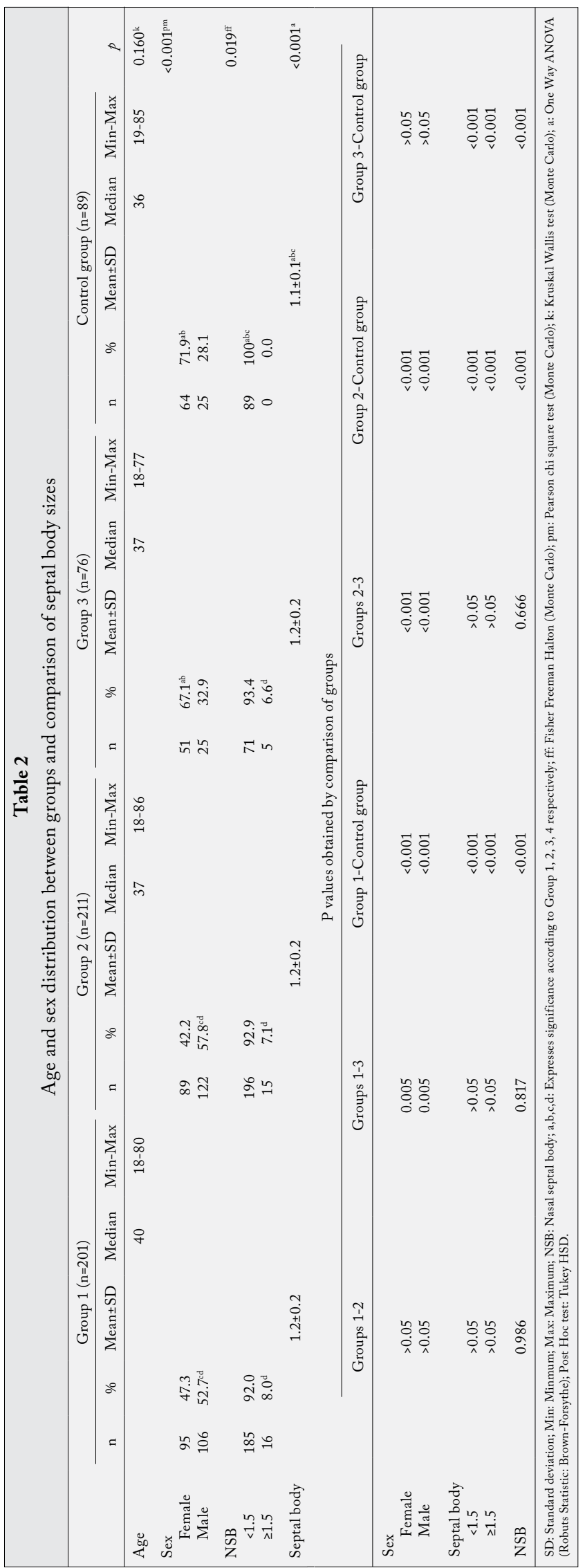


together with Bootstrap results in the comparison of two independent groups according to quantitative data. Tukey HSD test was used for one-way ANOVA post-hoc analysis, one of the parametric methods and the Kruskal-Wallis $\mathrm{H}$ test of nonparametric tests was used with the Monte Carlo simulation technique for the comparison of independent more than two groups according to quantitative data. Kendall's tau-b test was used to examine the correlations between the variables. In the comparison of categorical variables with each other, Exact and Monte Carlo simulation for Pearson chi-square test, exact results for Fisher exact, and Monte Carlo Simulation technique for FisherFreeman-Holton test were compared with BenjaminiHochberg corrected p-value. Quantitative variables were expressed as mean \pm SD (Standard deviation) and median (minimum) and categorical variables were expressed as $\mathrm{n}(\%)$. The variables were examined at a $95 \%$ confidence level and the p-value of $<0.05$ was considered statistically significant.

\section{RESULTS}

There were 577 patients in total. There were 201 (34.8\%) in Group 1, 211 (36.6\%) in Group 2, 76 (13.2\%) in Group 3, and 89 (15.4\%) in the control group,
Group 4. Of these, 299 (51.8\%) were female and 278 $(48.2 \%)$ were male. Mean age was $40.7 \pm 14.6$ years. There was no statistically significant age difference among groups $(p=0.160)$. There was no correlation between age and NSB width ( $\mathrm{p}=0.758)$ (Table 1,2).

Males in Group 1 and Group 2 had significantly larger NSB width ( $\mathrm{p}=0.002, \mathrm{p}=0.001$, respectively). NSB was significantly larger in males than females among all groups. NSB width of $\geq 1.5 \mathrm{~cm}$ was also significantly more prevalent among males $(\mathrm{p}<0.001)$ (Table 1).

The mean NSB width was $1.2 \pm 0.2 \mathrm{~cm}$. NSB width was significantly larger in all three study groups compared to the control group $(\mathrm{p}<0.001)$ (Table 2). While 541 patients had NSB width $<1.5 \mathrm{~cm}(93.8 \%), 36$ patients had NSB width $\geq 1.5 \mathrm{~cm}(6.2 \%)$. None of the members of the control group had NSB width $\geq 1.5 \mathrm{~cm}$. There were significantly more patients with NSB width $\geq 1.5$ in all study group compared to the control group $(p=0.019)$. There was no significant difference between the study groups in terms of NSB width and the number of patients with NSB width $\geq 1.5 \mathrm{~cm}$. Sinonasal pathologies and their distribution in Group 1 and Group 2 are presented in Table 3.

\section{Table 3}

Distribution of sinonasal pathologies in Group 1 and Group 2

\begin{tabular}{|c|c|c|c|c|c|}
\hline & \multicolumn{2}{|c|}{ Group $1(n=201)$} & \multicolumn{2}{|c|}{ Group $2(n=211)$} & \multirow[b]{2}{*}{$p$} \\
\hline & $\mathrm{n}$ & $\%$ & $\mathrm{n}$ & $\%$ & \\
\hline Septal deviation & & & & & $0.999 \mathrm{pe}$ \\
\hline Absent & 26 & 12.9 & 27 & 12.8 & \\
\hline Present & 175 & 87.1 & 184 & 87.2 & \\
\hline Acute sinusitis & & & & & $0.597^{\mathrm{pe}}$ \\
\hline Absent & 182 & 90.5 & 195 & 92.4 & \\
\hline Present & 19 & 9.5 & 16 & 7.6 & \\
\hline Chronic sinusitis & & & & & $0.004^{\mathrm{pe}}$ \\
\hline Absent & 160 & 79.6 & 141 & 66.8 & \\
\hline Present & 41 & 20.4 & 70 & 33.2 & \\
\hline Nasal polyposis & & & & & $<0.001^{\mathrm{pe}}$ \\
\hline Absent & 199 & 99.0 & 184 & 87.2 & \\
\hline Present & 2 & 1.0 & 27 & 12.8 & \\
\hline Chronic sinusitis & & & & & $0.003^{\mathrm{fe}}$ \\
\hline Absent & 160 & 79.6 & 141 & 66.8 & \\
\hline Unilateral & 36 & 17.9 & 67 & 31.8 & \\
\hline Bilateral & 5 & 2.5 & 3 & 1.4 & \\
\hline Nasal polyposis & & & & & $<0.001^{\mathrm{ff}}$ \\
\hline Absent & 199 & 99.0 & 184 & 87.2 & \\
\hline Unilateral & 2 & 1.0 & 26 & 12.3 & \\
\hline Bilateral & 0 & 0.0 & 1 & 0.5 & \\
\hline
\end{tabular}




\section{DISCUSSION}

Since the central part of the NSB nearly corresponds to the nasal valve region, enlargement in this structure can cause airway resistance. ${ }^{[9-12]} \mathrm{Kim}$ et al., ${ }^{[9]}$ showed that by decreasing NSB volume, the nasal valve area can be expanded. If the relatively narrow distal nasal valve section is considered, even very small changes in NSB dimensions may have significant consequences on nasal resistance. ${ }^{[4]}$ Because NSB may be confused with 'high septal deviation', coronal CT or magnetic resonance imaging is required to evaluate this structure. ${ }^{[9]}$ In patients who attended our clinic with sinonasal complaints, the preferred imaging method is paranasal CT. For this reason, similar to other studies in the literature, we also evaluated CT images. ${ }^{[3,13,14]}$

Koo et al. ${ }^{[15]}$ found that nearly a quarter of their patients had NSB. Arslan et a1. ${ }^{[16]}$ reported that $56 \%$ of their patients had NSB. Wong et al. ${ }^{[17]}$ measured remarkable decongestion following the application of topical decongestants to the NSB area in healthy volunteers. According to some authors, this structure is not a variation, but a conserved structure of the nasal septum that has specific histological components..$^{[1,4,11,17,18]}$

Costa et al. ${ }^{[1]}$ studied NSB in cadavers and measured the NSB dimensions with magnetic resonance images. They reported mean NSB width as $12.4 \mathrm{~mm}$, height $19.6 \mathrm{~mm}$, and length $28.4 \mathrm{~mm}$. Elwany et al. ${ }^{[18]}$ reported mean horizontal diameter of the NSB as $2.0 \pm 0.2 \mathrm{~cm}$. However, NSB may show less volume than normal in cadaveric evaluations. Demirci et al. ${ }^{[19]}$ studied NSB in patients with septum deviation and reported mean NSB width as $8.3 \pm 2.5 \mathrm{~mm}$. Yiğit et al. ${ }^{[20]}$ reported NSB in their allergic and non-allergic patients as $6.8 \pm 3.4 \mathrm{~mm}$ and $4.8 \pm 2.3 \mathrm{~mm}$ respectively. Setlur and Goyal ${ }^{[2]}$ reported mean NSB width as $9.3 \mathrm{~mm}$. In the current study, NSB width in Groups 1 to 4 were $1.21 \pm 0.2 \mathrm{~cm}, 1.2 \pm 0.2 \mathrm{~cm}$, $1.2 \pm 0.2 \mathrm{~cm}$, and $1.1 \pm 0.2 \mathrm{~cm}$, respectively (mean NSB in total was $1.2 \pm 0.2 \mathrm{~cm}$ ). Results between the studies, seem to vary according to the differences in imaging methods and patient selection (i.e. cadaveric or not). There is still no clear consensus about the normal sizes of NSB. We found significantly enlarged NSB in our study groups compared to the control group, and our results were consistent with the literature. ${ }^{[2,3,13,14,19,20]}$

Unlike other studies, we evaluated the patient groups separately. We expected a significant increase in NSB measurements in the presence of chronic pathologies (septal deviation, chronic sinusitis with/without nasal polyposis or AR) or co-existence of these pathologies. ${ }^{[2,3,13,19,20]}$ Hence, we evaluated the patients in three groups. However, we did not find any significant difference between these three groups in terms of NSB width. Although NSB plays a compensatory role in the nasal airflow, its expansion capacity seems limited. Despite being histologically similar, NSB contains fewer venous sinusoidal structures than the inferior turbinate. However, it is suggested that even the slightest changes in its dimensions can produce clinically significant outcomes. ${ }^{[21]}$

According to Gelera et al., ${ }^{[3]}$ with advancing age, NSB dimensions were considerably decreased in the control group and considerably increased in the disease group. However in the diseased group, except for the anterior part of NSB, their results did not reach significance. Some authors noted a decrease in NSB size with age, which they attributed to mucosal atrophy in advanced age..$^{[3,14,16]}$ In our study, we did not find any significant relationship between age and NSB width. Due to differences in study designs, the correlation between age and NSB dimensions is still uncertain in the literature.

Koo et al. ${ }^{[15]}$ found an increased prevalence of NSB in females but did not report statistical significance. Arslan et al. ${ }^{[16]}$ found increased prevalence in males. San et al., ${ }^{[14]}$ reported a significant increase in mean NSB area in males when compared to females. In our study, the NSB width was significantly larger in males. NSB size of $\geq 1.5 \mathrm{~cm}$ was also significantly more prevalent in males. Among patients in Group 1 and Group 2, the mean NSB was significantly greater in males than in females.

In this study, unlike other studies, we also investigated patients with markedly enlarged NSB (larger than $1.5 \mathrm{~cm}$ ). In the literature, there is no consensus regarding markedly enlarged NSB. Arslan et al. ${ }^{[16]}$ stated an NSB width $\leq 8 \mathrm{~mm}$ as 'normal'. In a study of Kim et al., ${ }^{[9]}$ the mean width for the markedly enlarged NSB was $16.4 \pm 2.2 \mathrm{~mm}$. From this standpoint, we defined NSB's larger than $1.5 \mathrm{~cm}$ as 'markedly enlarged' NSB. Accordingly, no 'markedly enlarged' NSB was identified in the control group. There was no significant difference between the three patient groups in terms of prevalence of markedly enlarged NSB. However, the number of patients with NSB width $\geq 1.5 \mathrm{~cm}$ was significantly increased in all patient groups when compared to the control group.

This study has several limitations. First, it is a retrospective study. Second, although, the NSB has commonly been evaluated by radiological techniques, the NSB is a dynamic structure and the nasal cycle may influence the measurements..$^{[1-3,13,14,16,19]}$ However, whether or not rhinomanometry, -a relatively dynamic test- is reliable and sensitive is still controversial. ${ }^{[22]}$ 
It may be efficient to also evaluate NSB with nasal endoscopy as suggested by Catalano et al. ${ }^{[22]} \mathrm{CT}$ scans may not provide as good a view as MRI scans do in assessing soft tissues. Nevertheless, further studies can investigate whether MR and $\mathrm{CT}$ are as reliable as dynamic tests.

Our study is the most extensive patient series study conducted for this purpose. As the authors of this study, we believe that treatments for enlarged NSB may need to be added to our treatment protocols for nasal and sinus-related diseases. In this regard, we believe that treatment success and patient satisfaction will increase.

In conclusion the results of our study are indicative that NSB is a compensatory dynamic structure that can vary in size in various sinonasal diseases. For otorhinolaryngologists, although enlarged NSB is relatively easy to diagnose and treat, there is limited information in the literature on this issue. We believe that our study and further research on this subject will greatly increase the awareness of clinicians. In this manner, inadequate expectations of post-operative patient satisfaction can be reduced.

\section{Declaration of conflicting interests}

The authors declared no conflicts of interest with respect to the authorship and/or publication of this article.

\section{Funding}

The authors received no financial support for the research and/or authorship of this article.

\section{REFERENCES}

1. Costa DJ, Sanford T, Janney C, Cooper M, Sindwani R. Radiographic and anatomic characterization of the nasal septal swell body. Arch Otolaryngol Head Neck Surg 2010;136:1107-10.

2. Setlur J, Goyal P. Relationship between septal body size and septal deviation. Am J Rhinol Allergy 2011;25:397400.

3. E Gelera J, Ojar D, Lim JH, Wee JH, Kim JW, Rhee CS. Radiographic Changes of the Nasal Septal Body Among Patients With Sinonasal Diseases. Clin Exp Otorhinolaryngol 2017;10:338-43.

4. Wexler D, Braverman I, Amar M. Histology of the nasal septal swell body (septal turbinate). Otolaryngol Head Neck Surg 2006;134:596-600.

5. Skin tests used in type I allergy testing Position paper. SubCommittee on Skin Tests of the European Academy of Allergology and Clinical Immunology. Allergy 1989;44:11-59.
6. Brozek JL, Bousquet J, Baena-Cagnani CE, Bonini S, Canonica GW, Casale TB, et al. Allergic Rhinitis and its Impact on Asthma (ARIA) guidelines: 2010 revision. J Allergy Clin Immunol 2010;126:466-76.

7. Rosenfeld RM, Piccirillo JF, Chandrasekhar SS, Brook I, Ashok Kumar K, Kramper M, et al. Clinical practice guideline (update): adult sinusitis. Otolaryngol Head Neck Surg 2015;152(2 Suppl):S1-S39.

8. Ashraf N, Bhattacharyya N. Determination of the "incidental" Lund score for the staging of chronic rhinosinusitis. Otolaryngol Head Neck Surg 2001;125:483-6.

9. Kim SJ, Kim HT, Park YH, Kim JY, Bae JH. Coblation nasal septal swell body reduction for treatment of nasal obstruction: a preliminary report. Eur Arch Otorhinolaryngol 2016;273:2575-8.

10. Bridger GP. Physiology of the nasal valve. Arch Otolaryngol 1970;92:543-53.

11. Cole P. The four components of the nasal valve. Am J Rhinol. 2003;17:107-10.

12. Wexler DB, Davidson TM. The nasal valve: a review of the anatomy, imaging, and physiology. Am J Rhinol 2004;18:143-50.

13. Hizli O, Kayabasi S, Ozkan D. Is Nasal Septal Body Size Associated With Inferior Turbinate Hypertrophy and Allergic Rhinitis? J Craniofac Surg 2020;31:778-81.

14. San T, Muluk NB, Saylisoy S, Acar M, Cingi C. Nasal septal body and inferior turbinate sizes differ in subjects grouped by sex and age. Rhinology 2014;52:231-7.

15. Koo SK, Kim JD, Moon JS, Jung SH, Lee SH. The incidence of concha bullosa, unusual anatomic variation and its relationship to nasal septal deviation: A retrospective radiologic study. Auris Nasus Larynx 2017;44:561-70.

16. Arslan M, Muderris T, Muderris S. Radiological study of the intumescentia septi nasi anterior. J Laryngol Otol 2004;118:199-201.

17. Wong E, Deboever N, Chong J, Sritharan N, Singh N. Isolated topical decongestion of the nasal septum and swell body is effective in improving nasal airflow. Am J Rhinol Allergy 2020;34:417-21.

18. Elwany S, Salam SA, Soliman A, Medanni A, Talaat E. The septal body revisited. J Laryngol Otol 2009;123:303-8.

19. Demirci S, Ertan N, Tuzuner A, Ozcan MK. Correlation between the septal body and the nasal turbinates in patients with deviated nasal septum. J Craniofac Surg 2016;27:166-9.

20. Yiğit Ö, Taşkın Ü, Acıŏglu E, Şişman AS, Huq Erdem G. Histological evaluation of the nasal swell body in allergic patients. Türk Otolarengoloji Arşivi 2013;51:41-4.

21. Wotman M, Kacker A. Should otolaryngologists pay more attention to nasal swell bodies? Laryngoscope 2015;125:1759-60.

22. Catalano P, Ashmead MG, Carlson D. RadioFrequency Ablation of Septal Swell Body. Ann Otolaryngol Rhinol 2015;2:1069. 